\title{
DAMPAK PENERAPAN PP NOMOR 46 TAHUN 2013 ATAS PEMBAYARAN PAJAK OLEH WAJIB PAJAK KPP PRATAMA MANADO
}

\author{
Yuli Rawun \\ Agus T. Poputra \\ Lintje Kalangi
}

(email: yulirawun@yahoo.co.id)

\begin{abstract}
In an effort to increase voluntary compliance with tax obligations and encourage the contribution of revenues from the UMKM sector, the Government has issued Government Regulation No. 46 2013. The new Tax Regulation has the advantage of rates that are used less than the previous fare, ie 1\% of gross turnover.Regulation No. 462013 taxpayer applies for personal and / or agency that has a certain gross income, ie income less than $4.8 \mathrm{M}$.

The aim of this study was to analyze the impact of adoption of Government Regulation No. 46 2013 of Paying Income Tax by Taxpayers at KPP Pratama Manado.

The analytical method used is using two different test samples / dependent groups (paired) or Paired Sample T Test. Paired Sample t test course used when the two groups are interconnected. Two paired sample means a sample with the same subject but have two different treatments or measurements of, for example, before and after.

Results of this study indicate that there is a difference between before and after the enactment of Government Regulation No. 46 Year 2013, but the difference that causes a decrease in the amount of tax paid by individual taxpayers who use the recording but for individual taxpayers who use the books there is no significant difference. As for corporate taxpayers that difference causes an increase on the amount of income tax payments by using final tax. Thus the application of Regulation No. 46 Year 2013 needs to be socialized again to taxpayers who are not registered in the KPP Pratama Manado in order to increase the amount of income tax payments.
\end{abstract}

Keywords: Impact, Government Regulation No. 46 2013, Paying, the Income Tax, Tax Payer.

\section{I}

PENDAHULUAN

Pembiayaan pengeluaran pemerintah lazimnya berasal dari pajak, hibah, bagian laba perusahaan negara/daerah, royalty, retribusi, dan utang. Dari sumber sumber pembiayaan tersebut, pajak merupakan sumber utama karena pemerintah memiliki kekuasaan memaksa atas rakyat untuk membiayai pengeluarannyamelalui pajak. Pajak dapat juga digunakan untuk berbagai tujuanselain membiayai pengeluaran pemerintah, diantaranya mendorong atau mengekang jenis-jenis perilaku tertentu, memperbaiki ketidaksempurnaan pasar, atau melakukan redistribusi pendapatan/kekayaan.

Pemanfaatan pajak sebagai sumber pembiayaan pengeluaran pemerintah di Indonesia semakin penting terkait menurunnya cadangan minyak dan gas yang selama ini telah menjadi salah satu sumber utama penerimaan pemerintah. Perkembangan penerimaan pajak di Indonesia mengalami peningkatan yang signifikan dari tahun ke tahun.

Pajak adalah kegiatan membayar sejumlah uang kepada negara yang diatur oleh UndangUndang (UU) yang berlaku yang digunakan untuk membiayai pengeluaran pemerintah dan pembangunan (Ahira, 2012). Hal ini tercakup dalam Anggaran Penerimaan dan Belanja Negara (APBN) dimana penerimaan dari pembayaran pajak ini adalah sumber pemasukan terbesar negara. Pajak juga merupakan salah satu pendapatan negara yang langsung dipungut dari berbagai objek pajak. Direktorat Jenderal Pajak yang secara struktural berada di bawah naungan Kementrian Keuangan merupakan salah satu instansi pemerintah yang mengemban tugas administrasi perpajakan ini. Dengan bermisikan menyelenggarakan fungsi administrasi perpajakan dan menerapkan UU Perpajakansecara adil dalam rangka membiayai penyelenggaraan negara demi kemakmuran rakyat, Direktorat Jenderal Pajak menurunkan misi tersebut kedalam misi fiskalnya, yakni untuk menghimpun penerimaan dari sektor pajak sehingga dapat menunjang pembiayaan 
pemerintah berdasarkan UUPerpajakan dengan tingkat efektifitas dan efisiensi yang tinggi (Annisa, 2011).

Penyumbang terbesar penerimaan pajak adalah pajak penghasilan (PPh), yakni sekitar 50persen dari penerimaantotal. Sebagai penyumbang terbesar, $\mathrm{PPh}$ mendapat perhatian khusus dari pemerintah yang diimplementasikan dalam bentuk reformasi mendasar atas jenis pajak tersebut. Pada 1983, pemerintah menerbitkan UUNomor7 tentang Pajak Penghasilan yang mengubah sistem pajak dari official-assessment system menjadi self-assessment system. Self assessment system memberikan kepercayaan wajib pajak untuk mendaftar, menghitung, membayar dan melaporkan kewajiban perpajakannya sendiri. Hal ini menjadikan kepatuhan dan kesadaran wajib pajak menjadi faktor yang sangat penting dalam hal untuk mencapai keberhasilan penerimaan pajak. Self assessment system menuntut adanya peran serta aktif dari masyarakat dalam pemenuhan kewajiban perpajakannya.Dalam perjalanan waktu, UU tersebut telah mengalami beberapa kali perubahan, yaitu menjadi UU Nomor 7 tahun 1991, UU Nomor 10 tahun 1994, UU Nomor 17 Tahun 2000, dan terakhir UU Nomor 36 tahun 2008 yang berlaku efektif per 1 Januari 2009.

Walaupun mengalami pertumbuhan sebagaimana dikemukakan sebelumnya, penerimaan $\mathrm{PPh}$ dan pajak lainnya di Indonesia masih dianggap kurang maksimal.Reformasi pajak adalah salah satu upaya yang telah dilakukan dalam rangka meningkatkan jumlah penyampaian pajak. Reformasi sendiri berartiperubahan yang mendasar. Suatu sistem perpajakan hendaknya memiliki sifat quasi constitutional. Iniberarti sistem tersebut berlaku dalam jangka panjang dan tidak dapat sering dilakukan reformasi.

Dalam upaya untuk meningkatkan pemenuhan kewajiban perpajakan secara sukarela (voluntary tax compliance) dan mendorong kontribusi penerimaan negara dari sektor UMKM, Pemerintah telah menerbitkan Peraturan Pemerintah (PP) Nomor 46 Tahun 2013. Peraturan Perpajakan yang baru ini memiliki kelebihan yaitu tarif yang digunakan lebih kecil dari tarif yang sebelumnya, yaitu 1\% dari omset. PPNomor46 Tahun 2013 berlaku untuk Wajib Pajak Orang pribadi dan/atau Badan yang memiliki penghasilan bruto tertentu, yaitu penghasilan yang kurang dari 4,8 $\mathrm{M}$ terbatas pada penghasilan dari usaha.

PPNomor 46 Tahun 2013 ini pada prinsipnya mengandung tiga tujuan utama yaitu untuk kemudahan tertib administrasi, transparansi dan peningkatan kontribusi masyarakat dalam pembangunan. Oleh karena itu sudah selayaknya PPNomor 46 Tahun 2013 ini dijadikan instrumen untuk menutup defisit penerimaan pajak di tiap-tiap Kantor Pelayanan Pajak (KPP). Masih banyak pelaku bisnis yang belum membayar pajak dengan sungguh-sungguh. Bagi mereka, pajak hanya dipandang sebelah mata dan dikesampingkan sebagai urusan yang tidak terlalu penting.

Untuk itu maka peneliti tertarik mengadakan penelitian sehubungan dengan masalah yang telah diuraikan di atas agar dapat mengetahui dampak dengan dikeluarkannya PP No 46 Tahun 2013AtasPembayaran Pajak Penghasilan Oleh Wajib Pajak KPP Pratama Manado.

\section{LANDASAN TEORI}

\section{Teori Perilaku Yang Direncanakan (Theory of Planned Behaviour)}

Theory of Planned Behavior (TPB) merupakan perluasan dari Theory of Reasoned Action (TRA). Dalam TRA dijelaskan bahwa niat seseorang terhadap perilaku dibentuk oleh dua faktor utama yaitu attitude toward the behavior dan subjective norms (Fishbein dan Ajzen, 1975), sedangkan dalam TPB ditambahkan satu faktor lagi yaitu perceived behavioral control (Ajzen, 1991).

Menurut Ajzen (2002) "Theory of Planned Behavior (TPB) menjelaskan bahwa perilaku yang ditentukan oleh individu timbul karena ada niat untuk berperilaku. Ada tiga faktor perilaku yang adanya niat untuk berperilaku.

1. Behavioral beliefs merupakan keyakinan individu akan hasil dari suatu perilaku dan evaluasi atas hasil tersebut.

2. Normative beliefs yaitu keyakinan tentang harapan normatif orang lain dan motivasi untuk memenuhi harapan tersebut.

3. Control beliefs merupakan keyakinan tentang keberadaan hal-hal yang mendukung atau menghambat perilaku yang akan ditampilkan dan persepsinya tentang seberapa kuat hal-hal yang mendukung dan menghambat perilakunya tersebut (perceived power)".

\section{Pengertian Pajak}


Pajak merupakan salah satu sumber pendanaan bagi negara dalam menjalankan peran pemerintahan. Pajak menjadi pemegang andil terbesar dalam pembangunan di seluruh aspek kehidupan di negara ini. Hal ini terjadi karena pajak merupakan sumber yang pasti dalam memberikan kontribusi kepada negara. Tidak dapat dipungkiri, bahwa tanpa pajak, pembangunan tidak akan berjalan lancar karena besarnya biaya yang diperlukan tidak akan bisa ditutupi dengan pinjaman dan bantuan luar negeri.

Menurut Undang-Undang Republik Indonesia No. 28 Tahun 2007, pajak adalah kontribusi wajib pajak kepada negara yang terhutang oleh pribadi/badan yang bersifat memaksa berdasarkan undangundang, dengan tidak mendapatkan imbalan secara langsung dan digunakan untuk keperluan negara bagi sebesar-besarnya kemakmuran rakyat.

Secara garis besar ciri-ciri yang terdapat pada pajak adalah sebagai berikut.

1. Iuran dari rakyat kepada kas negara, yang berhak memungut pajak hanyalah negara. Iuran tersebut berupa uang dan bukan berupa barang.

2. Berdasarkan undang-undang, pajak dipungut atau dilaksanakan berdasarkan dan dibawah aturan Undang-Undang Perpajakan yang berlaku.

3. Tanpa jasa timbal atau kontraprestasi dari negara yang secara langsung dapat ditunjuk, karena dalam pembayaran pajak tidak dapat ditunjukkan adanya kontraprestasi individual oleh pemerintah.

4. Digunakan untuk membiayai kebutuhan rumah tangga negara, yakni pengeluaran-pengeluaran yang bermanfaat bagi masyarakat luas.

\section{Fungsi Pajak}

Pajak juga mempunyai peranan yang sangat penting dalam kehidupan bernegara, khususnya sebagai sumber pembiayaan dan pembangunan Negara (Widyaningsih, 2011:3). Berdasarkan hal di atas maka pajak mempunyai beberapa fungsisebagai berikut.

1. Fungsi Penerimaan (budgeter)

Pajak berfungsi sebagai sumber dana yang diperuntukkan bagi pembiayaan pengeluaranpengeluaran pemerintah. Dalam APBN, pajak merupakan sumber penerimaan dalam negeri.

2. Fungsi Mengatur (regulator)

Pajak berfungsi sebagai alat untuk mengatur atau melaksanakan kebijakan di bidang sosial dan ekonomi.

3. Fungsi Stabilitas

Fungsi ini berhubungan dengan kebijakan untuk menjaga stabilitas harga (melalui dana yang diperoleh dari pajak) sehingga laju inflasi dapat dikendalikan.

4. Fungsi Redistribusi

Dalam fungsi redistribusi, lebih ditekankan unsur pemerataan dan keadilan dalam masyarakat. Fungsi ini terlihat dari adanya lapisan tarif dalam pengenaan pajak.

5. Fungsi Demokrasi

Pajak dalam fungsi demokrasi merupakan wujud system gotong royong.Fungsi ini dikaitkan dengan tingkat pelayanan pemerintah kepada masyarakat pembayar pajak.

\section{Syarat Pemungutan Pajak}

Agar pemungutan pajak tidak menimbulkan hambatan atau perlawananmenurut Mardiasmo (2013:

2) pemungutan pajak harus memenuhi syarat-syarat, sebagai berikut.

1. Pemungutan pajak harus adil (syarat keadilan)

Sesuai dengan tujuan hukum, yakni mencapai keadilan maka pelaksanaan Undang-Undang harus adil. Adil dalam perundang-undangan diantaranya mengenakan pajak secara umum dan merata, serta disesuaikan dengan kemampuan masing-masing Wajib Pajak. Sedangkan adil dalam pelaksanaannya yakni dengan memberikan hak bagi Wajib Pajak untuk mengajukan keberatan, penundaan dalam pembayaran dan mengajukan banding kepada majelis pertimbangan pajak.

2. Pemungutan pajak harus berdasarkan Undang-Undang (syarat yuridis). 
Di Indonesia, ketentuan perpajakan diatur dalam Undang-Undang Dasar 1945 pasal 23 ayat 2 yang memberikan jaminan hukum untuk menyatakan keadilan, baik bagi negara maupun masyarakat.

3. Pemungutan pajak tidak boleh mengganggu perekonomian (syarat ekonomis)

Pemungutan pajak tidak boleh mengganggu kelancaran kegiatan produksi maupun perdagangan, sehingga tidak menimbulkan kelesuan perekonomian masyarakat.

4. Pemungutan pajak harus efisien (syarat finansiil)

Sesuai dengan fungsi anggaran (budgetair), biaya pemungutan pajak harus dapat ditekan sehingga tidak melampaui hasil pemungutannya.

5. Sistem pemungutan pajak harus sederhana

Sistem pemungutan yang sederhana akan memudahkan dan mendorong masyarakat dalam memenuhi kewajiban perpajakannya. Syarat ini telah dipenuhi oleh Undang-Undang perpajakan yang baru.

\section{Teori-teori yang Mendukung Pemungutan Pajak}

Menurut Mardiasmo (2013:3), terdapat tiga teori dalam pemungutan pajaksebagai berikut.

1. Teori Asuransi

Negara Melindungi keselmatan jiwa, harta benda, dan hak- hak rakyatnya. Oleh karena itu rakyat harus membayar pajak yang diibaratkan sebagai suatu premi asuransi karena memperoleh jaminan perlindungan tersebut.

2. Teori Kepentingan

Pembagian beban pajak kepada rakyat didasarkan padakepentingan (misalnyapelindungan) masing-masing orang. Semakin besar kepentingan seseorang terhadap negara, makin tinggi pajak yang harus dibayar.

3. Teori Daya Pikul

Beban pajak untuk semua orang harus sama beratnya, artinya pajak harus dibayar sesuai dengan daya pikul masing-masing orang. Untuk mengukur daya pikul dapat digunakan 2 pendekatan yaitu :

a. unsur objektif, dengan melihat besarnya penghasilan atau kekayaan yang dimiliki oleh seseorang, dan

b. unsur subjektif, dengan memperhatikan besarnya kebutuhan materiil yang harus dipenuhi.

4. Teori Bakti

Dasar keadilan pemungutan pajak terletak pada hubungan rakyat dengan negaranya. Sebagai warga negara yang berbakti, rakyat harus selalu menyadari bahwa pembayaran pajak adalah sebagai suatu kewajiban.

5. Teori Asas Daya Beli

Dasar keadilan terletak pada akibat pemungutan pajak. Maksudnya memungut pajak berarti menarik daya belidari rumah tangga masyarakat untuk rumah tangga negara. Selanjutnya negara akan menyalurkannya kembali ke masyarakat dalam bentuk pemeliharaan kesejahteraan masyarakat. Dengan demikian kepentingan seluruh masyarakat lebih diutamakan.

\section{Asas Pemungutan Pajak}

Menurut Mardiasmo (2013:7), ada 3 Asas dalam Pemungutan Pajaksebagai berikut.

1. Asas Domisili (asas tempat tinggal)

Berdasarkan asas ini, Negara berhak mengenakan pajak atas suatu pengasilan yang diterima atau diperoleh orang pribadi atau badan yang bertempat tinggal di wilayahnya, baik penghasilan berasal dari dalam maupun luar negeri. Asas ini berlaku untuk Wajib Pajak dalam negeri.

2. Asas Sumber

Berdasarkan asas ini, Negara berhak mengenakan pajak atas penghasilan yang bersumber di wilayahnya, tanpa memperhatikan asal atau tempat tinggal Wajib Pajak. Contoh: Tenaga kerja asing bekerja di Indonesia maka dari penghasilan yang didapat di Indonesia akan dikenakan pajak oleh pemerintah Indonesia. 
3. Asas Kebangsaan

Sistem Pemungutan Pajak

Pengenaan pajak dihubungkan dengan kebangsaan suatu Negara.

Menurut Mardiasmo (2013:7), ada 3 sistem pemungutan pajak, yaitu:

1. Official Assessment System

Suatu sistem pemungutan yang memberikan wewenang kepada pemerintah (fiskus) untuk menetukan besarnya pajak yang terutang oleh Wajib Pajak.

2. Self Assessment System

Suatu sistem pemungutan pajak yang memberi wewenang kepada Wajib Pajak untuk menentukan sendiri besarnya pajak yang terutang.

3. With Holding System

Suatu sistem pemungutan pajak yang memberi wewenang kepada pihak ketiga (bukan fiskus dan bukan Wajib Pajak yang bersangkutan) untuk menentukan besarnya pajak yang terutang oleh Wajib Pajak.

\section{Pajak Penghasilan}

Menurut Rahman (2010:73), pajak penghasilan adalah pajak yang dikenakan atas penghasilan yang diterima atau diperoleh wajib pajak orang pribadi maupun badan dalam negeri, sehubungan dengan pekerjaan, jasa dan kegiatan.

Menurut Muljono (2009:1), subjek pajak penghasilan adalah Wajib Pajak, baik orang pribadi ataupun badan yang menurut ketentuan harus membayar, memotong atau memungut pajak yang terutang atas objek pajak.

\section{Kewajiban Pembukuan dan Pecatatan dalam Perpajakan}

Kewajiban pembukuan menurut ketentuan perundang-undangan perpajakan telah diatur dalam Pasal 28 UU Ketentuan Umum dan Tata Cara Perpajakan. Pada prinsipnya wajib pajak orang pribadi yang melakukan kegiatan usaha atau pekerjaan bebas dan wajib pajak Badan di Indonesia wajib menyelenggarakan pembukuan. Namun wajib pajak orang pribadi yang melakukan kegiatan usaha atau pekerjaan bebas yang menurut perundang-undangan perpajakan diperbolehkan menghitung penghasilan neto dengan menggunakan norma penghitungan.

Pembukuan atau pencatatan pajak dipergunakan sebagai dasar penghitungan pajak terhutang pada suatu tahun pajak, selain itu, informasi yang benar dan lengkap penghasilan wajib pajak sangat penting untuk dapat mengenakan pajak yang adil dan wajar senilai dengan kemampuan ekonomis wajib pajak. Untuk dapat menyajikan informasi yang di maksud wajib pajak harus menyelenggarakan pembukuan. Dimana dengan pembukuan tersebut wajib pajak dapat mengetahui sendiri berapa besarnya pajak terhutang, menyetor dan melapor pajak.

Pembukuan adalah suatu proses pencatatan yang dilakukan secara teratur untuk mengumpulkan data dan informasi keuangan yang meliputi harta, kewajiban, modal, penghasilan dan biaya, serta jumlah harga perolehan dan penyerahan barang atau jasa, yang ditutup dengan menyusun laporan keuangan berupa neraca, dan laporan laba rugi untuk periode Tahun Pajak tersebut.

Pencatatan yaitu pengumpulan data yang dikumpulkan secara teratur tentang peredaran atau penerimaan bruto dan/atau penghasilan bruto sebagai dasar untuk menghitung jumlah pajak yang terutang, termasuk penghasilan yang bukan objek pajak dan/atau yang dikenai pajak yang bersifat final.

Menurut Sari $(2013 ; 222)$ yang wajib menyelenggarakan pembukuan adalah:

1. Wajib Pajak Badan

2. Wajib Pajak Orang Pribadi yang melakukan kegiatan usaha atau pekerjaan bebas, kecuali wajib pajak Orang Pribadi yang peredaran brutonya dalam satu tahun lebih dari Rp. 4.800.000.000 (empat miliar delapan ratus juta rupiah).

Yang wajib menyelenggarakan pencatatan adalah:

1. Wajib Pajak Orang Pribadi yang melakukan kegiatan usaha atau pekerjaan bebas yang peredaran brutonya dalam satu tahun kurang dari Rp4.800.000.000,00 (empat miliar delapan ratus juta rupiah), dapat menghitung penghasilan neto dengan menggunakan norma penghitungan penghasilan neto, dengan syarat memberitahukan ke Direktur Jenderal Pajak dalam jangka waktu 3 bulan pertama dari tahunpajakyangbersangkutan; 
2. Wajib Pajak Orang Pribadi yang tidak melakukan kegiatan usaha atau pekerjaan bebas.

\section{Cara Menghitung Penghasilan Kena Pajak dan Tarif Pajak}

Besarnya Pajak Penghasilan dihitung berdasarkan Penghasilan Kena Pajak (PKP) dengan rumus: Penghasilan Kena Pajak $(\mathrm{PKP})=$ Penghasilan bersih pertahun - Penghasilan Tidak Kena Pajak $(\mathrm{PTKP})$. Menurut pasal 17 UU Nomor 36 tahun 2008, Tarif Pajak yang ditetapkan atas penghasilan wajib pajak perseorangan (orang pribadi) :

Tarif Pajak Orang Pribadi

\begin{tabular}{|l|c|}
\hline Penghasilan Kena Pajak (PKP) & Tarif Pajak \\
\hline Sampai dengan Rp 50.000.000 & $5 \%$ \\
Di atas Rp 50.000.000 - Rp 250.000.000 & $15 \%$ \\
Di atas Rp 250.000.000-Rp 500.000.000 & $25 \%$ \\
Di atas Rp 500.000.000 & $30 \%$ \\
\hline
\end{tabular}

Sumber: UU No. 36 Tahun 2008

Sedangkan Tarif Pajak yang ditetapkan bagi wajib pajak badan dalam negeri dan bentuk usaha tetap adalah :

1. Pada tahun 2009 tarif tertinggi yaitu $28 \%$ dapat diturunkan menjadi paling rendah $25 \%$ yang diatur dengan peraturan pemerintah.

2. Pada tahun 2010 ditetapkan tarif $25 \%$ bagi setiap Wajib Pajak Badan.

3. Wajib Pajak Badan dalam negeri yang berbentuk Perseroan Terbuka yang paling sedikit $40 \%$ dari jumlah keseluruhan saham yang disetor diperdagangkan di bursa efek Indonesia dan memenuhi persyaratan tertentu lainnya dapat memperoleh tarif sebesar 5\% lebih rendah dari tarif sebenarnya yang diatur dengan peraturan pemerintah.

\section{Pajak Penghasilan Final}

PPNomor46 Tahun 2013 adalah peraturan baru yang dikeluarkan oleh pemerintah untuk memberikan kemudahan bagi wajib pajak orang pribadi dan wajib pajak badan yang memiliki penghasilan bruto tertentu. PPNomor46 Tahun 2013 di tetapkan pada 1 Juli 2013. Pengenaan Pajak Penghasilan yang bersifat final tersebut ditetapkan berdasarkan pada pertimbangan perlunya kesederhanaan dalam pemungutan pajak, berkurangnya beban administrasi baik bagi Wajib Pajak maupun Direktorat Jenderal Pajak, serta memperhatikan perkembangan ekonomi dan moneter. Tujuan pengaturan ini adalah untuk memberikan kemudahan kepada Wajib Pajak yang menerima atau memperoleh penghasilan dari usaha yang memiliki peredaran bruto tertentu, untuk melakukan penghitungan, penyetoran, dan pelaporan Pajak Penghasilan yang terutang.

Pasal 3 ayat (1) dalam PPNomor46 Tahun 2013 berbunyi "Besarnya tarif Pajak Penghasilan yang bersifat final sebagaimana dimaksud dalam Pasal 2 adalah 1\% (satu persen)" Pengenaan Pajak Penghasilan didasarkan pada peredaran bruto dari usaha dalam 1 (satu) tahun dari Tahun Pajak terakhir sebelum Tahun Pajak yang bersangkutan. Jika dalam hal peredaran bruto kumulatif Wajib Pajak pada suatu bulan telah melebihi jumlah Rp.4.800.000.000,00 (empat miliar delapan ratus juta rupiah) dalam suatu Tahun Pajak, Wajib Pajak tetap dikenai tarif Pajak Final sampai dengan akhir Tahun Pajak yang bersangkutan. Namun apabila sudah masuk pada tahun pajak berikutnya maka dikenakan tarif pajak penghasilan berdasarkan ketentuan Undang - Undang Pajak Penghasilan.

\section{Penelitian Terdahulu}

Diatmika (2013) melakukan penelitian dengan judul Penerapan Akuntansi Pajak atas PPNomor 46 Tahun 2013 tentang PPh Atas Penghasilan dari Usaha Wajib Pajak yang Memiliki Peredaran Bruto Tertentu. Penelitian ini bertujuan untuk membandingkan kontribusi wajib pajak yang menerapkan PPNomor 46 tahun 2013 dengan wajib pajak yang tidak menerapkan PPNomor 46 Tahun 2013.

Kaimuddin (2014) melakukan penelitian dengan judul Efektifitas Penerapan PP Nomor 46 Tahun 2013 terhadap Penerimaan Pajak Penghasilan UKM pada KPP Pratama Malang Utara. Tujuan dari penelitian ini adalah untuk mengetahui realisasi penerimaan pajak terhadap pengembangan programprogram yang meningkatkan penerimaan pajak penghasilan yang berasal dari wajib pajak UKM, dan mengetahui efektifitas penerapan Peraturan Pemerintah no 46 tahun 2013 terhadap penerimaan pajak penghasilan UKM di Kantor Pelayanan Pajak Pratama Malang Utara. 
Eggie (2014) melakukan penelitian dengan judul Pengaruh Penerapan Peraturan Pemerintah (PP) Nomor 46 Tahun 2013 terhadap Penerimaan Pajak Negara di KPP Pratama Karees dan KPP Pratama Tegallega Bandung,

Penelitian ini memiliki beberapa persamaan dengan penelitian-penelitian tersebut di atas, yaitu untuk menilai sejauhmana dampak penerapan PP Nomor 46 Tahun 2013 ini terhadap wajib pajak yang memiliki peredaran bruto tertentu dalam hal ini adalah pengusaha UMKM. Sedangkan perbedaannya adalah terletak pada objek penelitian yang digunakan peneliti yaitu wajib pajak yang ada di KPP Pratama Manado dan metode analisis yang digunakan adalah metode analisis uji beda dengan Paired Sample T Test.

\section{KERANGKA KONSEPTUAL}

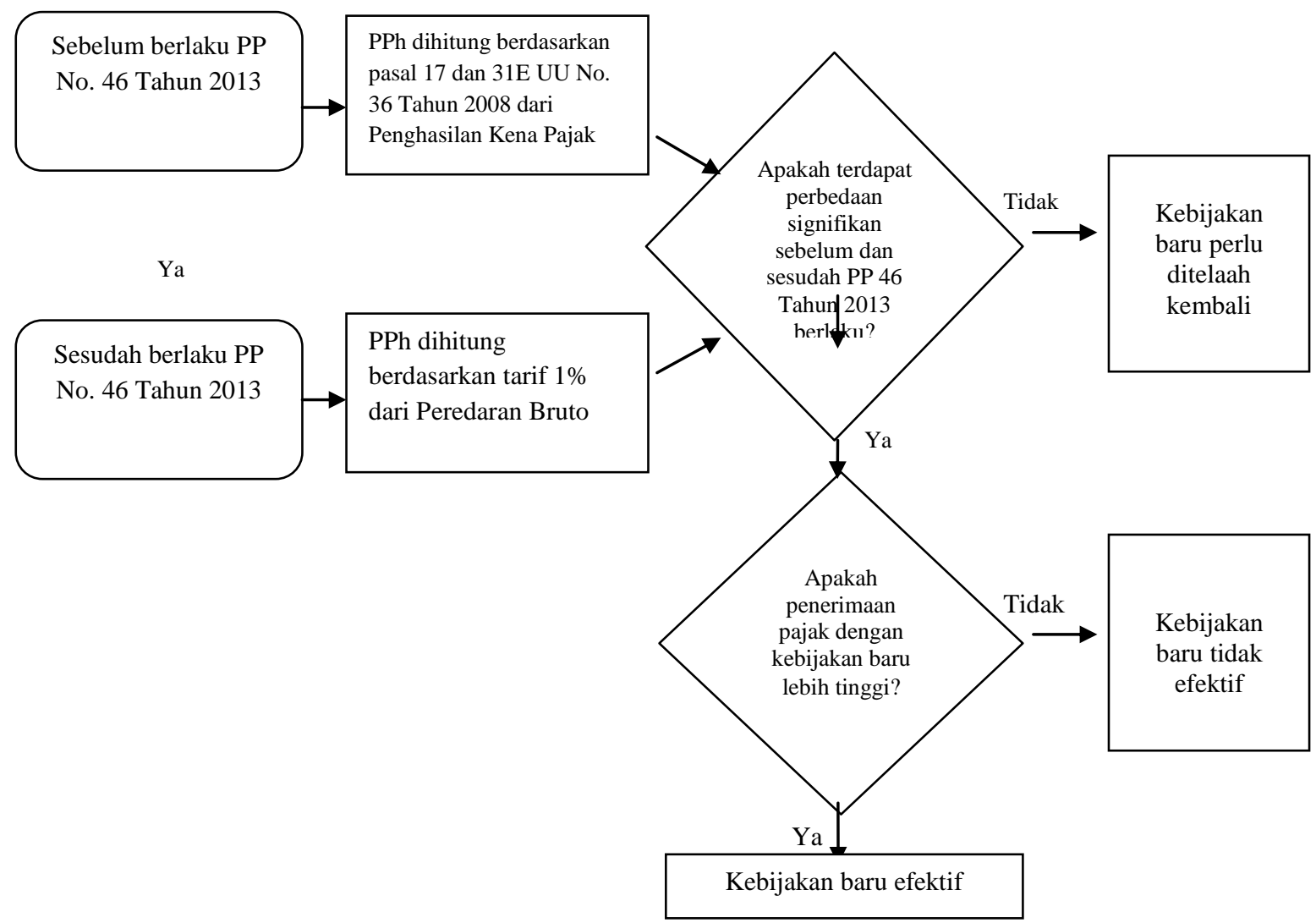

Sumber : Hasil olahan (2015)

\section{Hipotesis Penelitian}

Hipotesis yang dikembangkan dalam penelitian ini adalah sebagai berikut.

Ho1 : Tidak ada perbedaan tingkat pembayaran pajak oleh wajib pajak OP yang memiliki peredaran bruto tertentu yang melakukan pencatatan antara sebelum dan setelah pemberlakuan PP Nomor 46 Tahun 2013.

Ha 1 : Terdapat perbedaan tingkat pembayaran pajak oleh wajib pajak OP yang memiliki peredaran bruto tertentu yang melakukan pencatatan antara sebelum dan setelah pemberlakuan PP Nomor 46 Tahun 2013.

$\mathbf{H o}_{2}$ : Tidak ada perbedaan tingkat pembayaran pajak oleh wajib pajak OP yang memiliki peredaran bruto tertentu yamg melakukan pembukuan antara sebelum dan setelah pemberlakuan PP Nomor 46 Tahun 2013.

$\mathrm{Ha}_{2}$ : Terdapat perbedaan tingkat pembayaran pajak oleh wajib pajak OP yang memiliki peredaran bruto tertentu yang melakukan pembukuan antara sebelum dan setelah pemberlakuan PP Nomor 46 Tahun 2013.

Hoz : Tidak ada perbedaan tingkat pembayaran pajak oleh wajib pajak Badan yang memiliki peredaran bruto tertentu antara sebelum dan setelah pemberlakuan PP Nomor 46 Tahun 2013. 


\section{METODE ANALISIS}

Metode Analisis yang digunakan dalam penelitian ini adalah uji beda dengan menggunakan paired sample $t$ test. Paired sampel $t$ Test merupakan analisis dengan melibatkan dua pengukuran pada subjek yang sama terhadap suatu pengaruh atau perlakuan tertentu. Pada uji beda Paired sampl $t$ test, peneliti menggunakan sampel yang sama, tetapi pengujian terhadap sampel dilakukan sebanyak dua kali.

Hasil uji beda ini akan menunjukkan apakah ada perbedaan yang signifikan atau tidak ada perbedaaan yang signifikan terhadap pembayaran pajak oleh wajib pajak yang memiliki peredaran bruto tertentu antara sebelum dan setelah pemberlakuan PP Nomor 46 Tahun 2013.

\section{Metode Penelitian}

Adapun jenis data yang digunakan dalam penelitian ini adalah:

1. Data Kuantitatif, yaitu data yang berbentuk dokumen, daftar atau angka- angka yang dapat dihitung; dan

2. Data Kualitatif, yaitu data non angka yang sifatnya deskriptif dalam bentuk informasi lisan maupun tulisan yang diperoleh dari pihak wajib pajak yang berkompeten dalam memberikan informasi yang dibutuhkan dalam penelitian ini.

Sumber data yang digunakan dalam penelitian ini adalah:

1. Data Primer yaitu data yang diperoleh langsung dari hasil pengamatan (observasi) di lokasi penelitian dan wawancara dengan pihak-pihak yang berkepentingan; dalam hal ini adalah wajib pajak memiliki peredaran bruto tertentu.

2. Data Sekunder yaitu data yang diperoleh dari pihak lain secara kualitatif yang mempunyai relevansi dengan masalah dalam penulisan ini dan data yang diperoleh dari berbagai referensi berupa literatur dan buku, serta dokumen yang ada tersedia ditempat penelitian.

\section{Populasi dan Teknik Pengambilan Sampel}

Populasi dalam penelitian ini adalah wajib pajak di KPP Pratama Manado yang Memiliki Peredaran Usaha Tertentu. Sampel yang diambil menggunakan data tahun 2012 sebelum diberlakukannya PP Nomor 46 Tahun 2013 dan tahun 2014 setelah diberlakukannya PP Nomor 46 Tahun 2014. Objek yang diteliti adalah besarnya pajak penghasilan yang dibayarkan oleh wajib pajak yang memiliki peredaran bruto tertentu di KPP Pratama Manado.

\section{Tempat dan Waktu Penelitian}

Lokasi penelitian ini adalah di wilayah kerja KPP Pratama Manado untuk mengetahui seberapa besar dampak penerapanPPNomor 46 Tahun 2013apakah ada peningkatan atau penurunan terhadap penerimaan Negara atas wajib pajak yang memiliki peredaran bruto tertentu ini sebelum dan sesudah di berlakukannya PPNomor 46 Tahun 2013 ini.Waktu penelitian diperkirakan kurang lebih 3 bulan.

\section{Teknik Pengumpulan Data}

Pengumpulan data dilakukan untuk memperoleh data primer dan sekunder.

1. Penelitian lapangan

Penelitian lapangan dilakukan untuk memperoleh data primer dengan wawancara, obervasi dan dokumentasi.

2. Penelitian Kepustakaan

Penelitian ini dilakukan untuk memperoleh data sekunder dengan cara mengumpulkan literatur-literatur yang relevan dengan pembahasan penelitian yang dapat berupa buku, majalah, surat kabar, dan tulisan-tulisan ilmiah.

\section{ANALISIS DAN PEMBAHASAN HASIL PENELITIAN Hasil Penelitian}


Sebelum dilakukan analisis, di bawah ini akan dijabarkan data yang akan digunakan dalam penelitian ini. Data yang diperoleh antara lain jumlah Pajak Penghasilan Pasal 25 yang dibayarkan olehWajib Pajak Orang Pribadi yang menggunakan Pencatatan dan Pembukuan maupun Wajib Pajak Badan yang peredaran brutonya masih dibawah 4.8 M yang terdaftar di Kantor Pelayanan Pajak Pratama Manado pada Tahun 2012. Serta data jumlah Pajak Penghasilan Pasal 4 (2) yang dibayarkan oleh Wajib Pajak Orang Pribadi yang menggunakan Pencatatan dan Pembukuan maupun Wajib Pajak Badan yang peredaran brutonya belum melebihi 4,8 M pada Tahun 2014. Sampel diambil untuk 30 Wajib Pajak Orang Pribadi yang menggunakan Pencatatan, 30 Wajib Pajak Orang Pribadi yang menggunakan Pembukuan serta 30 Wajib Pajak Badan.

\section{Pengujian untuk Wajib Pajak Orang Pribadi yang menggunakan Pencatatan}

Tujuan pengujian hipotesis pertama adalah untuk mengetahui ada atau tidak adanya perbedaan pembayaran pajak oleh wajib pajak yang menggunakan pencatatan sebelum dan sesudah pemberlakuan PP Nomor 46 Tahun 2013.Hasil dari uji beda dengan metode paired sample t test adalah signifikan 0.000 lebih kecil dari 0.05 jadi $\mathrm{Ho}_{1}$ di tolak dan $\mathrm{Ha}_{1}$ diterima. Kesimpulannya adalah terdapat perbedaan yang signifikan sebelum dan sesudah penerapan PP Nomor 46 Tahun 2013.

\section{Pengujian untuk Wajib Pajak Orang Pribadi yang menggunakan Pembukuan}

Tujuan pengujian hipotesis kedua adalah untuk mengetahui ada atau tidak adanya perbedaan pembayaran pajak oleh wajib pajak yang menggunakan pembukuan sebelum dan sesudah pemberlakuan PP Nomor 46 Tahun 2013. Hasil uji beda dengan metode statistic Paired Sample T Test menunjukkan signifikan 0.122 lebih besar dari 0.05 . Kesimpulannya $\mathrm{Ho}_{2}$ diterima dan $\mathrm{Ha}_{2}$ ditolak karena tidak ada perbedaan yang signifikan antara sebelum dan sesudah penerapan PP Nomor 46 Tahun 2013.

\section{Pengujian untuk Wajib Pajak Badan yang mendapat Fasilitas}

Pengujian hipotesis ketiga adalah untuk mengetahui ada atau tidak adanya perbedaan pembayaran pajak oleh wajib pajak badan yang mendapat fasilitas sebelum dan sesudah pemberlakuan PP Nomor 46 Tahun 2013. Hasil uji beda dengan metode statistic Paired Sample T Test menunjukkan signifikan 0.122 lebih besar dari 0.05 . Kesimpulannya $\mathrm{Ho}_{2}$ diterima dan $\mathrm{Ha}_{2}$ ditolak karena tidak ada perbedaan yang signifikan antara sebelum dan sesudah penerapan PP Nomor 46 Tahun 2013.

\section{Pembahasan Hasil Penelitian untuk Wajib Pajak Orang Pribadi (Pencatatan)}

Hasil yang diperoleh dari uji beda dengan menggunakan alat uji beda statistik parametrik Paired sample t-testadalah signifikan 0.000 dibawah 0.05 untuk wajib pajak orang pribadi yang menggunakan pencatatan di tahun 2012 dan 2014. Ini menunjukan hipotesisHo $\mathrm{H}_{1}$ ditolak dan $\mathrm{Ha}_{1}$ diterima karena terdapat perbedaan yang signifikan antara sebelum penerapan PP Nomor 46 dan sesudah PP Nomor 46. Hal ini mengindikasikan bahwa terdapat perbedaan yang cukup signifikan atas pembayaran pajak oleh wajib pajak yang menggunakan pencatatan pada tahun 2012 dan 2014.

Hasil penelitian ini juga menunjukan bahwa dengan adanya penerapan PP Nomor 46 Tahun 2013 (pajak final) memberikan dampakpenurunan terhadap jumlah pembayaran pajak penghasilan oleh wajib pajak orang pribadi yang menggunakan pencatatan. Penurunan ini disebabkan karena dalam perhitungan pajak penghasilan langsung dikalikan $1 \%$ dari peredaran bruto menghasilkan jumlah pajak penghasilan yang lebih kecil. Sedangkan sebelum penerapan PP Nomor 46 Tahun 2013 (pajak tidak final) perhitungan pajak penghasilan untuk wajib pajak orang pribadi yang menggunakan pencatatan dihitung dulu dengan asumsi penghasilan bruto adalah sebesar $25 \%$ - 40\%. Persentase yang cukup besar ini mengakibatkan penghasilan kena pajak setelah dikurangkan dengan jumlah penghasilan tidak kena pajak menjadi besar. Ini berdampak pada perhitungan jumlah pajak penghasilan yang akan dibayarkan oleh wajib pajak menjadi besar jika dihitung dengan tarif progresif sesuai dengan UU Nomor 36 Tahun 2008

Kesimpulan terhadap pengujian yang telah dilakukan atas hipotesa yang pertama adalah pemberlakuan PP Nomor 46 Tahun 2013 kurang efektif dan perlu dikaji lagi karena menyebabkan penurunan atas jumlah pajak penghasilan yang dibayarkan oleh wajib pajak yang sudah terdaftar di KPP Pratama Manado yang selama ini menggunakan pencatatan.Namun disamping itu karena perhitungannya yang mudah akan menghasilkan wajib pajak baru yang belum terdaftar di KPP Pratama Manado yang 
selama ini belum sadar akan kewajibannya dalam hal membayar pajak dan belum pernah membayar pajak penghasilannya akan berkontribusi untuk membayar pajak penghasilannya.

\section{Pembahasan Hasil Penelitian untuk Wajib Pajak Orang Pribadi (Pembukuan)}

Hasil yang diperoleh dari uji beda dengan menggunakan alat uji beda statistik parametrik Paired sample t-testuntuk wajib pajak orang pribadi (pembukuan) pada adalah signifikan 0.122lebih besar 0.05 Ini menunjukan hipotesis $\mathrm{Ho}_{2}$ diterima dan $\mathrm{Ha}_{2}$ ditolak karena tidak ada perbedaan yang signifikan antara sebelum penerapan PP Nomor 46 dan sesudah PP Nomor 46.

Hal ini mengindikasikan bahwa untuk wajib pajak orang pribadi yang menggunakan pembukuan pada tahun 2012 tidak ada perbedaan yang cukup signifikan atas pembayaran pajak penghasilannya. Jumlah pajak penghasilan yang di bayarkan oleh wajib pajak yang menggunakan pembukuan lebih tinggi jika menggunakan pajak final daripada perhitungan pajak tidak final berdasarkan tarif progresif UU Nomor 36 Tahun 2008 pada margin laba kotor kurang dari 12\%. Begitu pula pada tahun 2014 tidak terdapat perbedaan yang signifikan atas pembayaran pajak penghasilan oleh wajib pajak yang menggunakan pembukuan karena pajak penghasilan yang dihitung berdasarkan UU Nomor 36 Tahun 2008 hampir sama jumlahnya jika dihitung dengan menggunakan tarif pajak final yaitu 1\% dari peredaran bruto.

Kesimpulan atas hipotesa kedua untuk wajib pajak orang pribadi yang menggunakan pembukuan adalah kurang efektif karena tidak terdapat perbedaan yang signifikan sebelum dan sesudah pemberlakuan PP Nomor 46 Tahun 2013 atas jumlah pajak penghasilan yang dibayarkan oleh wajib pajak pembukuan tersebut.

\section{Pembahasan Hasil Penelitian untuk Wajib Pajak Badan}

Hasil yang diperoleh dari uji beda dengan menggunakan alat uji beda statistik parametrik Paired sample t-testuntuk wajib pajak badan tahun 2012 dan 2014 adalah signifikan 0.000 dibawah 0.05. Ini menunjukan hipotesisHo $\mathrm{S}_{3}$ ditolak dan $\mathrm{Ha}_{3}$ diterima karena terdapat perbedaan yang signifikan antara sebelum penerapan PP Nomor 46 dan sesudah PP Nomor 46.

Hal ini mengindikasikan bahwa untuk wajib pajak badan yang peredaran brutonya belum melebihi Rp. 4.800.000.000,- setahun mendapat fasilitas 50\% dari tarif pajak badan yang seharusnya berlaku sesuai dengan pasal 31E UU Nomor 36 Tahun 2008,terdapat perbedaan yang cukup signifikan atas pembayaran pajak penghasilannya baik tahun 2012 maupun tahun 2014. Jumlah pajak penghasilan yang di bayarkan oleh wajib pajak badan tersebut lebih besar jumlahnya jika menggunakan pajak final daripada perhitungan pajak tidak final berdasarkan UU Nomor 36 Tahun 2008 Pasal 31E. Jika margin laba yang diperoleh wajib pajak badan adalah $8 \%$ maka perhitungan pajak penghasilan baik menggunakan tarif $1 \%$ dari peredaran bruto ataupun tarif $12.5 \%$ dari penghasilan kena pajak (karena mendapat fasilitas $50 \%$ dari tarif pajak yang berlaku untuk wajib pajak badan sebesar 25\%) hasilnya adalah sama.

Kesimpulan untuk hipotesa ketiga adalah dengan diberlakukannya PP Nomor 46 Tahun 2013 maka terdapat perbedaan yang signifikan untuk jumlah pajak yang harus dibayarkan oleh wajib pajak badan yang mendapat fasilitas. Berarti penerapan PP Nomor 46 Tahun 2013 ini sangat efektif untuk wajib pajak badan karena tarif final $1 \%$ dari peredaran bruto menyebabkan kenaikan jumlah pajak penghasilan yang dibayarkan oleh wajib pajak badan.

\section{PENUTUP}

\section{Kesimpulan}

Berdasarkan hasil pembahasan dari penelitian yang dilakukan mengenai dampakpenerapan PP Nomor 46 Tahun 2013 atas pembayaran pajak penghasilan olehwajib pajak yang terdaftar di KPP Pratama Manado, maka dapat ditarik kesimpulan sebagai berikut.

1. Hasil uji beda untuk wajib pajak orang pribadi yang menggunakan pencatatan menunjukkan perbedaan signifikan secara statistik antara sebelum dan sesudah penerapan PP Nomor 46 
Tahun 2013.Perbedaan ini menunjukkan penurunan dari jumlah pajak penghasilan yang harus dibayarkan oleh wajib pajak, sehingga dari segi fiskus kebijakan baru tersebut kurang efektif. Namun jika melihat konteks yang lebih luas yaitu dari segi transparansi dan perluasan wajib pajak maka kebijakan ini bisa saja efektif dalam meningkatkan jumlah penerimaan pajak penghasilan secara keseluruhan.

2. Hasil uji beda untuk wajib pajak orang pribadi yang menggunakan pembukuan menunjukkan tidak ada perbedaan yang signifikan secara statistik antara sebelum dan sesudah penerapan PP Nomor 46 Tahun 2013.

3. Hasil uji beda untuk wajib pajak badan menunjukkan ada perbedaan yang signifikan secara statistik antara sebelum dan sesudah penerapan PP Nomor 46 Tahun 2013. Perbedaan ini meupakan kenaikan dari jumlah pajak penghasilan yang harus dibayarkan oleh wajib pajak badan yang mendapat fasilitas, sehingga kebijakan baru tersebut efektif bagi Fiskus.

\section{Saran}

Berdasarkan hasil pembahasan dan pengujian hipotesa ada beberapa temuan yang pelu diperhatikan dalam penelitian ini, maka dapat diberikan saran sebagai berikut.

1. Untuk meningkatkan jumlah pembayaran pajak oleh wajib pajak maka perlu ditingkatkan lagi sosialisasi kepada masyarakat yang belum terdaftar di KPP Pratama Manado tentang PP Nomor 46 tahun 2013 dimana perhitungan pajak penghasilannya sangat memudahkan masyarakat untuk menghitung sendiri berapa besar pajak penghasilan yang harus dibayarkan.

2. Perlu dilakukan survei lapangan ke wajib pajak yang terdaftar di KPP Pratama Manado oleh Fiskus untuk mengetahui secara langsung besaran peredaran bruto yang diperoleh wajib pajak sehingga peredaran bruto yang dilaporkan mendekati yang sebenarnya.

3. Perlu diberikan himbauan dan teguran kepada wajib pajak yang terdaftar di KPP Pratama yang belum melakukan pembayaran pajak penghasilan sesuai dengan PP Nomor 46 Tahun 2013 yaitu $1 \%$ dari peredaran bruto.

\section{Keterbatasan Penelitian}

Penelitian ini bukanlah suatu penelitian yang sempurna di mana masih memiliki beberapa keterbatasan sebagai berikut.

1. Penelitian ini hanya dilakukan untuk wajib pajak yang terdaftar di KPP Pratama Manado, sehingga kesimpulan yang dapat diambil tidak dapat digeneralisir untuk wajib pajak Indonesia secara keseluruhan.

2. Penelitian yang dilakukan dengan menggunakan metode statistik paired sample $t$ testini hanyalah salah satu cara untuk melihat perbedaan yang diperoleh sebelum dan sesudah PP Nomor 46 Tahum 2013 namun perlu dikaji lebih dalam lagi tentang faktor-faktor yang mempengaruhi perbedaan tersebut.

\section{DAFTAR PUSTAKA}

Anonim. PP Republik Indonesia Nomor 46 Tahun 2013 tentang Pajak Penghasilan atas Penghasilan dari Usaha yang Diterima atau Diperoleh Wajib Pajak yang Memiliki Peredaran Bruto tertentu.

Anonim. UU Republik Indonesia Nomor 28 Tahun 2007 tentang Ketentuan Umum dan Tata Cara Perpajakan.

Anonim. UU Republik Indonesia Nomor 20 Tahun 2009 tentang Usaha Mikro, Kecil dan Menengah.

Anonim. UU Nomor 36 Tahun 2008 tentang Perubahan Keempat atas UU Nomor 7 Tahun 1983 tentang Pajak Penghasilan.

Adi, KwartoNomor 2007. Analisis Usaha Kecil Menengah, CV. Andi Offset, Yogyakarta

Allingham, M., and A. Sandmo (1972), "Income Tax Evasion: A Theoretical Analysis," Journal of Public Economics, 1: 323-338.

Alm, J. (1993), “Tax Evasion, ” http://www.urban.org/pubs/taxation/alm.html.

Andreoni, J., B. Erard, and J. Feinstein (1998), “Tax Compliance,” Journal of EconomicLiterature, XXXVI: 818-860. 
Atep Adya Barata, 2011, Panduan Lengkap Pajak Penghasilan, Cetakan Pertama, Penerbit Visimedia, Jakarta.

Brooks, N. (2001), Key Issues in Income Tax: Challenges of Tax Administration and Compliance, Asian Development Bank 2001 Tax Conference, Tokyo.

Chattopadhyay, S., and A. Das-Gupta (2002), "The Personal Income Tax in India: Compliance Costs and Compliance Behavior Taxpayers," National Institute of Public Finance and Policy, New Dehli.

Diatmika. 2013, Penerapan Akuntansi Pajak atas PP Nomor 46 Tahun 2013 tentang PPh Atas Penghasilan dari Usaha Wajib Pajak yang Memiliki Peredaran Bruto Tertentu.

Diaz, dan Bambang. 2011. Faktor-Faktor yang Mempengaruhi Pengusaha Kecil dan Mikro Mendaftar Menjadi Wajib Pajak Orang Pribadi, Balai Pustaka

Direktorat Jenderal Pajak. 2013. Leaflet Pajak Wajib Pajak yang Memiliki Peredaran Bruto Tertentu (PP Nomor 46 Tahun 2013). (www.pajak.o.id)

Diana Sari, 2013. Konsep Dasar Perpajakan, PT. Refika Aditama

Djoko Muljono, 2006, Akuntansi Pajak, Penerbit ANDI, Yogyakarta.

Djoko Muljono, 2010. Panduan Brevet Pajak, Penerbit ANDI, Yogyakarta.

Eggie. 2014, Pengaruh Penerapan Peraturan Pemerintah (PP) Nomor 46 Tahun 2013 terhadap Penerimaan Pajak Negara di KPP Pratama Karees dan KPP Pratama Tegallega Bandung,

Fischer, C. M., M. Wartick, and M. Mark (1992), "Detection Probability and Taxpayer Compliance: A Review of Literature, "Journal of Accounting Literature, 11: 1-46.

H. Zaharuddin, 2006, Menggali Potensi Wirausaha, Edisi Kedua, Penerbit CV. Dian Anugerah Prakasa, Bekasi.

Ibrahim, Syarif. 2013. Pengenaan PPh Final untuk wajib Pajak dengan Peredaran Bruto tertentu, Sebuah Konsep Kesederhanaan Pengenaan PPh untuk Meningkatkan Voluntary Tax Compliance.

Icek Ajzen, 2002, The Theory Of Planned Behavior, dalam Organizational Behavior and Human Decision Processes 50. Academic Press Inc.

Kaimuddin. 2014, Efektifitas Penerapan PP Nomor 46 Tahun 2013 terhadap Penerimaan Pajak Penghasilan UKM pada KPP Pratama Malang Utara.

Mardiasmo. 2013. Perpajakan Edisi Revisi, CV Andi Offset, Yogyakarta

N.J. Feldmann, 2010, Perpajakan Indonesia, Penerbit Salemba Empat, Jakarta.

Rahmawati. 2014, "Penerapan PP Nomor 46 tahun 2013 terhadap Besaran Pajak Terutang UMKM di Kabupaten Sleman", Skripsi, tidak dipublikasikan

Resmi, Siti. 2008. Perpajakan Studi \& Kasus, Edisi 4. Jakarta: Salemba Empat.

Resyniar. 2014, "Persepsi Usaha Mikro Kecil Menengah Terhadap Penerapan PP Nomor 46 Tahun $2013 "$.

Roth, J. A., J. T. Scholz, and A. D. Witte (1989), Taxpayer Compliance, Vol. 1: An Agenda for Research, Philadelphia: University of Pennsylvania Press.

Teguh Hadi Wardaya, 2013. Pajak Terapan Brevet A dan B, Tax Sys (PT. Bina Artha Profesitama)

Wenzel, M. (2005), "Motivation or Rationalization? Causal Relations between Ethics, Norms, and Tax Compliance, ”Journal of Economic Psychology, 26: 491-508.ofesitama) 